\title{
The school library that germinates in a very unfertile land and acts as a moon rise for Malawi's rural children's library
}

\author{
George G. Makhalira \\ Librarian and advocate of Children Libraries \\ Malawi, \\ Africa \\ makhalirag@yahoo.co.uk
}

\begin{abstract}
The paper highlights a school library service in a rural set up in Lilongwe, Malawi. It is a school library that has germinated from a ray of hope from the primary school staff, the surrounding community members and leaders (village chiefs, religious leaders, etc.) who garnered to support their children to access printed materials.

In conclusion, the paper details how the author and the IASL 2014 Children Book Award has boosted the primary school library window to the world and the promotion of reading and access to printed materials.
\end{abstract}

Keywords: School library- rural- Malawi, Rural Primary School-Africa, IASL Book Award-2014. Reading culture-Promotion, Africa, Malawi.

\section{Introduction}

In recent years, the Malawi government in collaboration with other stakeholders has been in the forefront in sensitizing the public on the importance of child rights with particular emphasis on the right to education and protection. However, there is a growing concern that there is a problem of reading culture in Malawi. This observation seems to be correct based on the education structure and its supportive structures that are currently used throughout the country.

Studies carried out on the provision of school libraries throughout the world, has shown that countries that have taken the provision of school libraries to its nationals, has greatly improved in their reading culture and development of education. You may note on the Malawi Profile data which the IASL uphold on its website as shown below. 


\begin{tabular}{|l|l|}
\hline Population and literacy & $\begin{array}{l}\text { Population 16.36 million } \\
\text { Literacy level: 62.7\% level }\end{array}$ \\
\hline Overview of School Library situation & $\begin{array}{l}\text { It is not yet developed due to lack of funds } \\
\text { to support the growth and acquisition of } \\
\text { reading materials }\end{array}$ \\
\hline Links to important associations/contacts & $\begin{array}{l}\text { Civil Service Forum for Library and } \\
\text { Information Personnel(CSFLIP)Malawi and } \\
\text { IASL Regional Manager Africa. }\end{array}$ \\
\hline $\begin{array}{l}\text { Particular issues and needs of the Reading materials and partnerships } \\
\text { country }\end{array}$ \\
\hline Famous authors $\quad$ Dr Chimombo,M, Mr. Nsandala,S. \\
\hline Links to literature of the country Book Publishers Ass. Of Malawi \\
\hline Links to SL programs or advocacy CSFLIP,IASL and Book Pub. Ass.Malawi \\
\hline News/reports $\quad$ MALA Bulletin, CSFLIP Newsletter \\
\hline
\end{tabular}

Malawi profile for iasl website

\section{School library services landscape}

The school library service in Malawi has been influenced by numerous factors for instance:

- the early missionaries who mostly settled in rural areas to introduce Christian doctrines and education,

- the attainment of self-rule from the colonial government(British)

- the current government policies that had inclusively embedded the Universal Access of Education-UNESCO, Millennium Development Gaols (MDG's) and Malawi Development Gaols Strategy Paper.

- Illiteracy and poverty levels are among the notable ones.

Achitabwino (2005) said the future of each and every nation lies in the hands of the youth. If the young generation is nurtured taking into account the developments of tomorrow, that mark the basis of building a better tomorrow. Generations of tomorrow shall judge generations of today by the barometer of socio-economic developments inherited to them. Robert Wergeworth argues that perhaps the most important task each generation performs for the next generation is the transmittal of its culture. It is a fundamental aspect of a family and societal life.

Culture is not genetically inherent. The youth of the nation will learn more about culture through being taught and reading for proper acquaintance with their roots. It is for that reason that Wedgeworth stressed that libraries are institutions created in order to assist in accomplishing the task of transmitting culture. In varying proportions and under varying conditions, libraries preserve culture and make it available for current and future generations. It must be clear to everyone, says Lawal-Solarin, that unless our children are properly and well educated, the goal of a developed society will be extremely difficult to achieve in Africa. Books for children are the most important tool with which we can achieve this objective. For the sake of the future of our country, we need to "catch the children young" and educate them thoroughly not only through formal education but also by cultivating the habit for reading for information and pleasure. Having inculcated the habit it will be of extreme mutual benefit to the children and the society at large. 
Teresa Samuel Ibrahim lectures that the recognition of the importance of the children's books is a reflection not only of changes of understanding and methods but also of the appreciation that today's children are tomorrow's adults. The advantages and opportunities that reading offers will be secured if the new generation grows up with the habit of using books.

Mphando Full Primary School- 2014 IASL books for children awardee Mphando is a primary school that is located in a remote rural west of the Capital City of Malawi -Lilongwe. It uses a co -education system and has classes from Grade 1 to Grade 8. It has pupils from age ranges from 6 t0 16 years old and it is a government aided school. The school has a library that was designated in one of the rooms within the school blocks. It uses simple wooden book shelves, reading tables and chairs of wooden forms.

\section{Library Support and Utilization}

The Mphando School Library is been in existence due to the desire of the teaching staff and the community around the school for untiring support for the library. The headmaster of the school formed a village library committee so that it acts as a body for promoting the development of the library. The committee is chaired by the local members in the village. Membership consists of local chiefs, women, headmaster, and priest among the membership.

The library committee has a major role of mobilizing resources to assist in maintaining the requirements for the information center. It also acts as a platform for encouraging the rural masses the importance of encouraging their children to read books through organizing events related to the use of reading books. Events like role models of the community like Policemen/women, Nurses, etc. come to address children in order to emulate them. The school does have reading open days where school children show case their ability to read books and recite poems.

\section{Challenges}

The challenges facing the school library in Malawi includes funding, acquisition of locally produced materials, and security of the materials, preservation of the materials, maintenance of the library and the oral culture.

Funding has been a major problem to government aided schools because they can not afford to purchase up to date relevant library materials due to inadequate financial resources. Locally produced materials are in short supply to meet the demand for easy reading books as the collection development is bias for imported library materials. Mita, C (2011) lamented that "Malawians has lost preservation of the materials is a big challenge due to poor production and high usage of the little reading materials available.. Quality is poor and it cannot sustain to endure the high usage by pupils.

\section{IASL Book Award-2014}

The IASL Book Award which the Mphando Primary won in 2014 became a big booster to the development of the school library as it was struggling to acquire relevant books for its users. Illiteracy and poverty is high in this area so the book award came at the right time to minimize the challenges faced by this primary school library.

The award assisted in purchasing dictionaries in both local and foreign language, vernacular books, life skills books, pictorial/illustrated books for young learners. 


\section{Conclusion}

We the people of MALAWI we are very thankful to the International Association of School Librarianship for the Books for Children Award that helped us to buy books for Mphando Primary School. We look forward to your visit to our library in future and continue remember to support us. We have also made available electronic pictures in order for you colleagues appreciate the wonderful work by IASL in Malawi the Warm Heart of Africa.

Thank You!!!!!

\section{References}

Achitabwino,P.(2005) Need for Children's Librarians in Malawi. LIS News; A Librarian Blog (online) Available.

Dhamabaworn, K. (2004). Children's Accuracy and Competency. Available on line at: http://www.childrenlibrabry.com/projectactivity/123=html/rsaeduchallege.pdf, Accessed on $10^{\text {th }}$ March, 2015.

Luban, J. (1998). Children Libraries and Literacy. Available on line at:

http://www.childrenlibrabry.com/projectactivity/123=html/rsaeduchallege.pdf , Accessed on $21^{\text {st } M a r c h, ~} 2015$.

Johnson, P.(2004) Fundamentals of collection development and management. Chicago: American Library Association.

Markless, S and Streatfield, D (2006) Evaluating the impact of your library. London: Facet Publishing.

Yesner, B. L. and Murray, M. M. (1993). Developing Literature Based Reading_Programms. Neal-Schuman Publishers: New York, London 